\title{
Crystal Structure of 7,11-bis(2,4-dichlorophenyl)-2,4-dimethyl-2,4- diazaspiro[5.5] undecane -1,3,5,9-tetraone and its computational studies
}

\author{
MOHAMMAD SHAHIDUL ISLAM ${ }^{\mathrm{a}}$, ASSEM BARAKAT $^{\mathrm{a}, \mathrm{c}, *}$, \\ ABDULLAH MOHAMMED AL-MAJID ${ }^{\mathrm{a}}$, SAIED M SOLIMAN ${ }^{\mathrm{b}, \mathrm{c}}$, \\ HAZEM A GHABBOUR ${ }^{\mathrm{d}, \mathrm{e}}$ and HOONG-KUN FUN ${ }^{\mathrm{d}, \mathrm{f}}$ \\ ${ }^{a}$ Department of Chemistry, College of Science, King Saud University, P. O. Box 2455, Riyadh 11451, \\ Saudi Arabia \\ ${ }^{b}$ Department of Chemistry, Rabigh College of Science and Art, King Abdulaziz University, \\ P. O. Box 344, Rabigh 21911, Saudi Arabia \\ ${ }^{\mathrm{c}}$ Department of Chemistry, Faculty of Science, Alexandria University, P.O. Box 426, Ibrahimia, \\ Alexandria 21321, Egypt \\ ${ }^{\mathrm{d}}$ Department of Pharmaceutical Chemistry, College of Pharmacy, King Saud University, \\ P.O. Box 2457, Riyadh 11451, Saudi Arabia \\ ${ }^{\mathrm{e}}$ Department of Medicinal Chemistry, Faculty of Pharmacy, Mansoura University, \\ Mansoura 35516, Egypt \\ ${ }^{f}$ X-Ray Crystallography Unit, School of Physics, Universiti Sains Malaysia, Penang, 11800 Malaysia \\ e-mail: ambarakat@ksu.edu.sa
}

MS received 28 May 2015; revised 4 September 2015; accepted 11 September 2015

\begin{abstract}
Crystals of 7,11-bis(2,4-dichlorophenyl)-2,4-dimethyl-2,4-diazaspiro[5.5] undecane -1,3,5,9tetraone were grown in polar solvents and subjected to single crystal X-ray diffraction. The molecular crystal is Triclinic, $P-1, a=8.3734$ (19) $\AA, b=12.382$ (3) $\AA, c=12.871$ (3) $\AA, \alpha=66.639(7)^{\circ}, \beta=85.148(7)^{\circ}$, $\gamma=70.690(6)^{\circ}, V=1154.5(5) \AA^{3}, Z=2, D_{\text {calc }}=1.519 \mathrm{~g} \mathrm{~cm}^{-3}$. The optimized molecular structure of the studied compound using B3LYP/6-311G(d,p) method showed good agreement with the X-ray structure. The electronic and spectroscopic properties of the title compound were predicted. The NBO calculations were used to calculate the natural atomic charges at the different atomic sites as well as the intramolecular charge transfer (ICT) interactions among the most significant natural orbitals. The high $\mathrm{LP}(\mathrm{N}) \rightarrow \mathrm{BD} *(2) \mathrm{C}-\mathrm{O}$ ICT interaction energies indicate strong electron delocalization from the lone pair of the $\mathrm{N}$-atoms of the pyrimidinetrione ring to the adjacent carbonyl groups. In contrast, the small $\mathrm{LP}(\mathrm{O}) \rightarrow \mathrm{BD} *(1) \mathrm{C}-\mathrm{H}$ stabilization energies $\left(\mathrm{E}^{(2)}\right)$ indicated weak $\mathrm{C}-\mathrm{H}-\mathrm{O}$ interactions. Experimentally, the studied compound showed the most intense electronic transition band at $232 \mathrm{~nm}$ which is calculated using TD-DFT method as a shoulder at $231.3 \mathrm{~nm}(\mathrm{f}=0.0832)$ and it belongs to $\mathrm{H}-3 / \mathrm{H}-1 \rightarrow \mathrm{L}+1$ and $\mathrm{H}-2 \rightarrow \mathrm{L}+2$ excitations. The GIAO calculated ${ }^{1} \mathrm{H}$ and ${ }^{13} \mathrm{C}$ NMR chemical shifts showed good correlations with the experimental data.
\end{abstract}

Keywords. Spiro heterocycles; [5+1] cyloaddition; Michael Addition; $N, N$-Dimethyl barbituric acid; DFTcomputation.

\section{Introduction}

The nitrogen containing spiro-heterocyclic scaffolds are available in a variety of biologically active natural products obtained from plants and animals. ${ }^{1}$ The heterocyclic spiro-compounds display a large range of pharmaceutical and biological importance. ${ }^{2}$ Spirocycles compounds are also useful for the synthesis of some novel catalysts and special organic optoelectronics synthetic materials. ${ }^{3}$ A large number of naturally occurring alkaloids possessing a spiro-carbon in their

*For correspondence skeleton have shown biological activity in agriculture and medicine. They also act as nicotinic receptor antagonists and possess antibiotic, antimicrobial and anticancer properties. ${ }^{4-10}$ However, current literature reveals that some diazaspiro[5.5] undecane-1,3,5,9tetraones motif possess a variety of therapeutic and biological properties such as anticonvulsant, ${ }^{11}$ antifungicidal, ${ }^{12}$ potent sedative-hypnotic, ${ }^{13}$ antibacterial ${ }^{14}$ and CNS depressant properties. ${ }^{15}$ Moreover, this type of compounds can also be used as a yellow organic pigment and as a disperse dye with strong fluorescence property as it contains barbituric acid moiety. ${ }^{16}$ Michael addition reaction is one of the remarkable 
tool for C-C bond constructing process ${ }^{17}$ especially, intermolecular double-Michael reaction which is the most powerful tool for the synthesis of spirocyclic product from the non-cyclic starting materials. As part of our ongoing research progress this work describes the synthesis of 7,11-bis(2,4-dichlorophenyl)-2,4-dimethyl-2, 4-diazaspiro[5.5] undecane -1,3,5,9-tetraone spiro-heterocyclic using a very simple and robust intermolecular double-Michael addition reaction with excellent yield and regioselectivity. The studied compound has been fully characterized by X-ray diffraction (XRD), FTIR and NMR spectroscopy. Also, the DFT/B3LYP calculations have been performed to study the molecular structure characteristics of the studied compound. The electronic and spectroscopic properties of the studied compound have been predicted using the same level of theory. The TD-DFT calculations were used to predict and assign the electronic spectra of the studied compound. NBO calculations were performed to predict the natural atomic charges and study the different intramolecular charge transfer (ICT) interactions occurring in the studied system. The ${ }^{1} \mathrm{H}$ and ${ }^{13} \mathrm{C}$ chemical shifts were calculated theoretically and compared with the experimental data.

\section{Experimental}

\subsection{Materials and methods}

All the glassware were oven-dried before use and the reactions were conducted under an inert atmosphere. The progress of the reaction was monitored by TLC (Merck Silica Gel 60 F-254 thin layer plates). The chemicals were purchased from Aldrich and Fluka and were used without further purification, unless otherwise stated. Petroleum ether (PE), hexane and ethyl acetate were distilled prior to use especially for column chromatography. All the major solvents were dried by using standard drying techniques mentioned in the literature. Melting points were measured on a Gallen-kamp melting point apparatus in open glass capillaries and are uncorrected. IR Spectra were measured as $\mathrm{KBr}$ pellets on a Nicolet 6700 FT-IR spectrophotometer. The NMR spectra were recorded on a Jeol-400 NMR spectrometer. ${ }^{1} \mathrm{H}-\mathrm{NMR}(400 \mathrm{MHz})$, and ${ }^{13} \mathrm{C}$-NMR (100 MHz) were run in deuterated chloroform $\left(\mathrm{CDCl}_{3}\right)$. Chemical shifts $(\delta)$ are referred in terms of ppm and $J$-coupling constants are given in $H z$. Mass spectrometric analysis was conducted by using ESI mode on AGILENT Technologies 6410triple quad LC/MS instrument. The electronic spectrum of the studied compound was measured using Perkin Elmer, Lambda 35, UV/Vis spectrophotometer, (Dichloromethane): $\lambda_{\max }=232 \mathrm{~nm}$.
2.2 Synthesis of 7,11-bis(2,4-dichlorophenyl)-2,4dimethyl-2,4-diazaspiro[5.5]undecane-1,3,5,9tetraone

A solution of $N, N$-dimethyl barbituric acid ( $2 \mathrm{mmol}$, $312.1 \mathrm{mg}$ ) and diarylidene acetone derivative $(2 \mathrm{mmol}$, $734 \mathrm{mg}$,) in $10 \mathrm{~mL}$ of dry $\mathrm{CH}_{2} \mathrm{Cl}_{2}$ were charged into a $50 \mathrm{~mL}$ round bottom flask under inert atmosphere. The $\mathrm{Et}_{2} \mathrm{NH}(2.5 \mathrm{mmol})$ was then added to the reaction mixture and stirred at room temperature for up to $1.5-2 \mathrm{~h}$, until TLC showed complete consumption of both the reactants. After the completion of reaction, the crude product was directly subjected to column chromatography using $100-200$ mesh silica gel and ethyl acetate/ $n$-hexane $(2: 8, \mathrm{v} / \mathrm{v})$ as an eluent to afford the pure products. The solid products were further crystallized from a mixture of $\mathrm{DCM} / \mathrm{Et}_{2} \mathrm{O}$. (957 mg, $1.82 \mathrm{mmol}, 91 \%)$; M.p. $185-187^{\circ} \mathrm{C}$; ${ }^{1} \mathrm{H}-\mathrm{NMR}$ (400 $\left.\mathrm{MHz}, \mathrm{CDCl}_{3}\right) \delta: 2.57 \& 2.61(\mathrm{dd}, 2 \mathrm{H}, J=16.12$ $\left.\mathrm{Hz}, 4.40 \mathrm{~Hz}, \mathrm{CH}_{2(\mathrm{e})}\right), 2.96$ (s, 3H, $\left.-\mathrm{NCH}_{3}\right), 3.26$ (s, 3H, $-\mathrm{NCH}_{3}$ ), 3.42 (t, $2 \mathrm{H}, J=15.40 \mathrm{~Hz}, \mathrm{CH}_{2(\mathrm{a})}$ ), $4.67 \& 4.71(\mathrm{dd}, 2 \mathrm{H}, J=15.40 \mathrm{~Hz}, 4.40 \mathrm{~Hz}, \mathrm{CH})$, $7.11-7.14(\mathrm{~m}, 2 \mathrm{H}, \mathrm{Ar}-\mathbf{H}), 7.15-7.18$ (m, 2H, ArH), 7.38 (s, 2H, Ar-H); ${ }^{13} \mathrm{C}-\mathrm{NMR}\left(100 \mathrm{MHz}, \mathrm{CDCl}_{3}\right)$ $\delta: 28.70,29.14,43.57,45.24,57.36,127.75,129.86$, $130.50,131.91,133.02,134.00,149.55,169.43$, 169.91, 205.60; IR $\left(\mathrm{KBr}, \mathrm{cm}^{-1}\right) v_{\max }=2920,1718$, 1673, 1444, 1375, 1108, 1045, 828, 747, 465; [Anal. Calcd. for $\mathrm{C}_{23} \mathrm{H}_{18} \mathrm{Cl}_{4} \mathrm{~N}_{2} \mathrm{O}_{4}$ : C, 52.30; $\mathrm{H}, 3.43 ; \mathrm{N}, 5.30 \%$; Found: C, 52.41; H, 3.45; N, 5.37\%]; LC/MS (ESI, $\mathrm{m} / \mathrm{z}$ ): $\left[\mathrm{M}^{+}\right]$, found 526.10, $\mathrm{C}_{23} \mathrm{H}_{18} \mathrm{Cl}_{4} \mathrm{~N}_{2} \mathrm{O}_{4}$ requires 526.00 .

\subsection{Single crystal X-ray measurements}

The target compound was obtained as crystals by slow diffusion of diethyl ether solution of pure compound in dichloromethane at room temperature for 2 days. Data were collected on a Bruker APEX-II D8 Venture area diffractometer, equipped with graphite monochromatic Mo K $\alpha$ radiation at 293 (2) K. Cell refinement and data reduction were carried out by Bruker SAINT. SHELXS-97 ${ }^{18,19}$ was used to solve structure. The final refinement was carried out by full-matrix least-squares techniques with anisotropic thermal data for nonhydrogen atoms on $F 2$. All the hydrogen atoms were placed in calculated positions. The crystal structure of the target compound is shown in figure 1).

The structure of the titlecompound was confirmed by $\mathrm{X}$-ray crystal structure analysis (Bruker AXS GmbH). CCDC-1042004 contains the supplementary crystallographic data for this compound. These data can be 


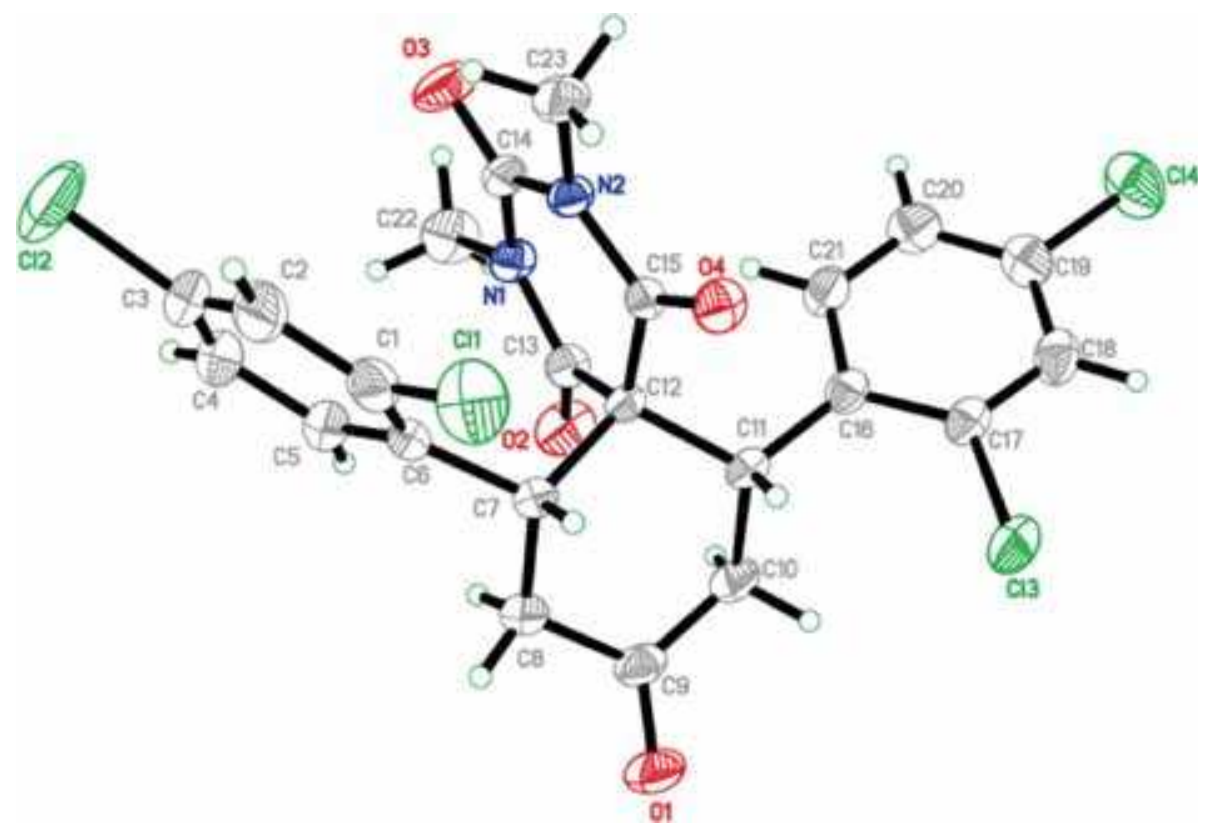

Figure 1. The ORTEP diagram of the final X-ray model of the title compound with displacement ellipsoids drawn at $40 \%$ probability level.

obtained free of charge from the Cambridge Crystallographic Data Centre via www.ccdc.cam.ac.uk/data request/cif.

\subsection{Computations}

All the quantum chemical calculations of the studied compound were performed by applying DFT method with the B3LYP functional and $6-311 \mathrm{G}(\mathrm{d}, \mathrm{p})^{20 \mathrm{a}}$ basis set using Gaussian 03 software. ${ }^{20 \mathrm{~b}}$ The input file was taken from the CIF obtained from our reported Xray single crystal measurement. The geometry was optimized by minimizing the energies with respect to all the geometrical parameters without imposing any molecular symmetry constraints. GaussView4.121 and Chemcraft $^{22}$ programs have been used to draw the structure of the optimized geometry and to visualize the HOMO and LUMO levels. Frequency calculations showed the absence of any imaginary frequency modesconfirmedthat the optimized structure is an energy minimum. The electronic spectra of the studied compound were calculated by the TD-DFT method. The natural bond orbital analyses were performed using the NBO calculations as implemented in the Gaussian 03 package ${ }^{23}$ at the B3LYP/6-311G(d,p)level. The ${ }^{1} \mathrm{H}$ and ${ }^{13} \mathrm{C}$ NMR chemical shifts were calculated using GIAO method at the same level of theory.

\section{Results and Discussion}

\subsection{Synthesis and characterization}

The synthetic pathway to the title compound is summarized in scheme 1 . The starting compounds, $N, N$ dimethyl barbituric acid is commercially available, diarylidene was obtained by the condensation of 2,4dichlorobenzaldehyde with acetone. ${ }^{24}$ The reaction of $N, N$-dimethyl barbituric acid with equimolar amount of dienonein DCM using diethylamine as a base afforded the target compound 7,11-bis(2,4-dichlorophenyl)-2,4-dimethyl-2,4-diazaspiro[5.5] undecane -1 , 3,5,9-tetraone with excellent yield. The compound was characterized by a combined applications of ${ }^{1} \mathrm{H},{ }^{13} \mathrm{C}$ and GCMS spectroscopy.

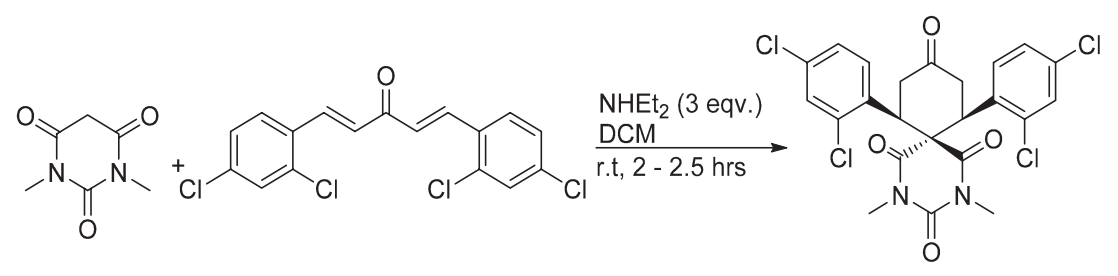

Scheme 1. Preparation of the title compound. 
Table 1. The crystal and experimental data of the title compound.

\begin{tabular}{|c|c|}
\hline & Title compound \\
\hline Empirical formula & $\mathrm{C}_{23} \mathrm{H}_{18} \mathrm{Cl}_{4} \mathrm{~N}_{2} \mathrm{O}_{4}$ \\
\hline Formula weight & 528.19 \\
\hline Temperature & $100(2) \mathrm{K}$ \\
\hline Wavelength (Mo $K \alpha$ radiation, $\lambda$ ) & $0.71073 \AA$ \\
\hline Crystal system & Triclinic \\
\hline Space group & $\mathrm{P}-1$ \\
\hline Unit cell dimensions & $\begin{array}{c}a=8.3734(19) \AA, \\
b=12.382(3) \AA, \\
c=12.871(3) \AA \\
\alpha=66.639(7)^{\circ}, \\
\beta=85.148(7)^{\circ}, \\
\gamma=70.690(6)^{\circ}\end{array}$ \\
\hline Volume & $1154.5(3) \AA^{3}$ \\
\hline $\mathrm{Z}$ & 2 \\
\hline Density (calculated) & $1.519 \mathrm{Mg} \mathrm{m}^{-3}$ \\
\hline Absorption coefficient & $0.55 \mathrm{~mm}^{-1}$ \\
\hline$F(000)$ & 540 \\
\hline$R_{\text {int }}$ & 0.043 \\
\hline$R_{g t}$ & 0.046 \\
\hline$w R\left(F^{2}\right)$ & 0.127 \\
\hline Crystal size & $0.41 \times 0.35 \times 0.31 \mathrm{~mm}$ \\
\hline Theta range for data collection & $2.6-29.6^{\circ}$ \\
\hline Reflections collected/ unique & 21764,3429 \\
\hline Completeness to theta $=29.6^{\circ}$ & $99.8 \%$ \\
\hline Refinement & \\
\hline Goodness-of-fit on $F^{2}$ & 1.02 \\
\hline Diffractometer & $\begin{array}{l}\text { Bruker APEX-II } \\
\text { D8 venture }\end{array}$ \\
\hline Absorption correction & $\begin{array}{c}\text { multi-scan } \\
S A D A B S \text { V2012/1 }\end{array}$ \\
\hline CCDC number & 1042004 \\
\hline
\end{tabular}

\subsection{Crystal structure of title compound}

The asymmetric unit of the synthesized compound contains one molecule (figure 1, table 1). The molecule is constructed from spiro compound between a cyclohexanone ring and pyrimidine-trione ring. The cyclohexanone ring (C7-C12) adopts the expected chair conformation and it is nearly perpendicular to the mean plane of the pyrimidine ring $(\mathrm{C} 12 / \mathrm{C} 13 / \mathrm{N} 1 / \mathrm{C} 14 / \mathrm{N} 2 / \mathrm{C} 15)$ with the dihedral angle of 81.04 (2) (figure 2). Bond lengths and angles are within normal ranges. In the crystal packing, figure 3 , shows that the molecules are linked into a 3-dimensional network via three nonclassical hydrogen bonds between $\mathrm{C} 7-\mathrm{H} 7 \mathrm{~A} \cdots \mathrm{O} 1$, $\mathrm{C} 10-\mathrm{H} 10 \mathrm{~B} \cdots \mathrm{Cl} 2$ and $\mathrm{C} 23-\mathrm{H} 23 \mathrm{C} \cdots \mathrm{O} 4$ (table S1, see Supporting Information).

\subsection{Optimized Molecular Geometry}

The optimized molecular structure of the studied compound is shown in figure 4 . The calculated bond lengths and bond angles compared to the experimental data are given in table 2 . The compound possesses $\mathrm{C}_{1}$ point group. There is a good agreement between the calculated geometric parameters (bond distances and bond angles) and the experimental X-ray structural parameters obtained from the crystallographic information file (CIF). The calculated root mean square deviations (RMSD) of the bond distances and bond angles are $0.013 \AA$ and $1.229^{\circ}$, respectively. In general, most of bond distances are overestimated where the maximum deviation from the experimental data is $0.032 \AA(2.06$

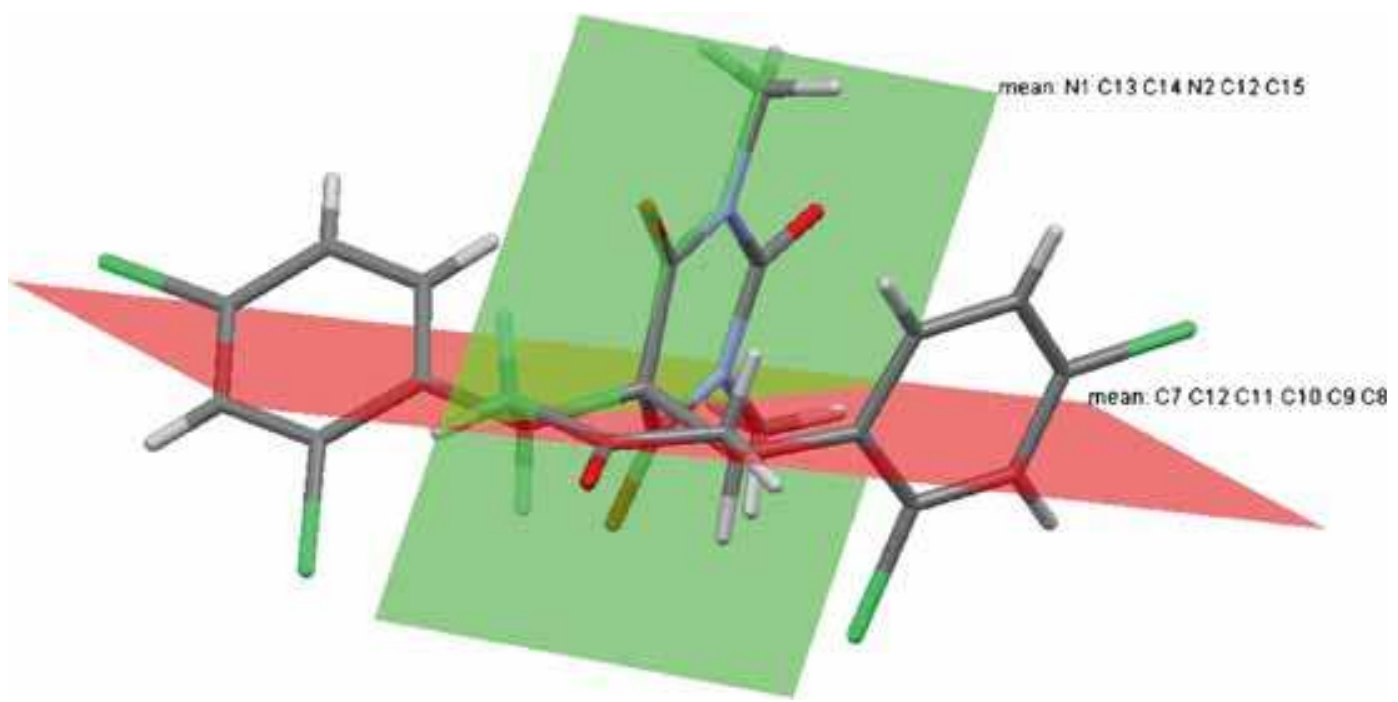

Figure 2. The dihedral angle between cyclohexanone and pyrimidine rings. 


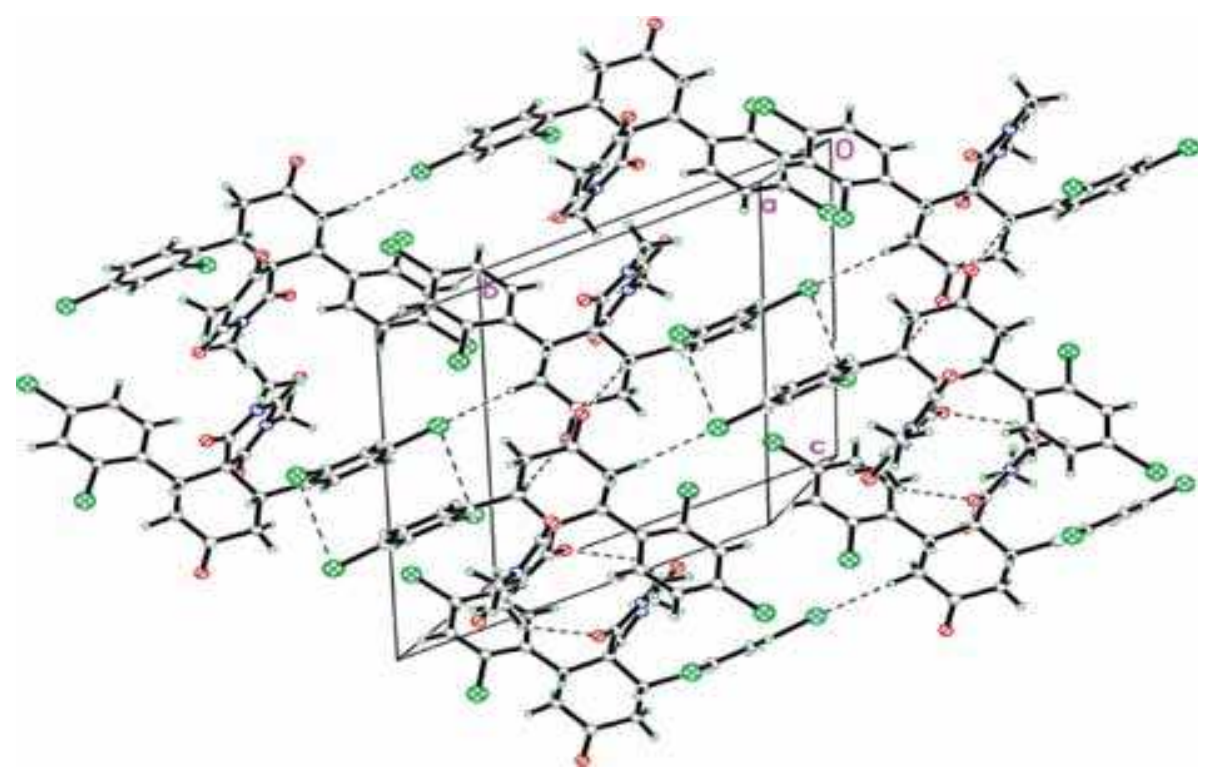

Figure 3. Crystal packing showing intermolecular $\mathrm{C}-\mathrm{H} \cdots \mathrm{O}$ and $\mathrm{C}-\mathrm{H} \cdots \mathrm{Cl}$ interactions as dashed lines.

$\%$, C29-C31).The calculated bond distances and bond angles showed good agreement with the experimental data. The correlation graphs shown in figure S1 (Supplementary Information) gave high correlation coefficients for the bond distances $\left(\left(\mathrm{R}^{2}=0.996\right)\right.$ and bond angles $\left(\mathrm{R}^{2}=0.931\right)$.

\subsection{Natural atomic charge}

The distribution of atomic charges plays an important role in determining many electronic properties such as dipole moment, molecular polarizability and hyperpolarizability. From this point of view, we calculated the natural atomic charges at the different atomic sites and the results are presented in table 3. The $\mathrm{O}$ and $\mathrm{N}$ atoms of the studied compound have the most electronegative natural charge where the $\mathrm{O}$-atoms are more electronegative than $\mathrm{N}$-sites. These atoms are responsible for the polarity of the compound (3.7404 D). The natural atomic charges at the two $\mathrm{N}$-atoms are almost the same.Two of the $\mathrm{Cl}$-atoms $(\mathrm{Cl} 2$ and $\mathrm{Cl} 4)$ are less electropositive than the others $(\mathrm{Cl} 1$ and $\mathrm{Cl} 3)$. Interestingly, the $\mathrm{O} 6$ atom has higher negative natural atomic charge than $\mathrm{O} 8$. We noted that, the $\mathrm{Cl} 2$ and $\mathrm{Cl} 4$ atoms are in close contact to $\mathrm{O} 8$-atom where the $\mathrm{Cl}-\mathrm{O}$ intramolecular distance is predicted around $3.3 \AA$. This could explain the different natural charges at

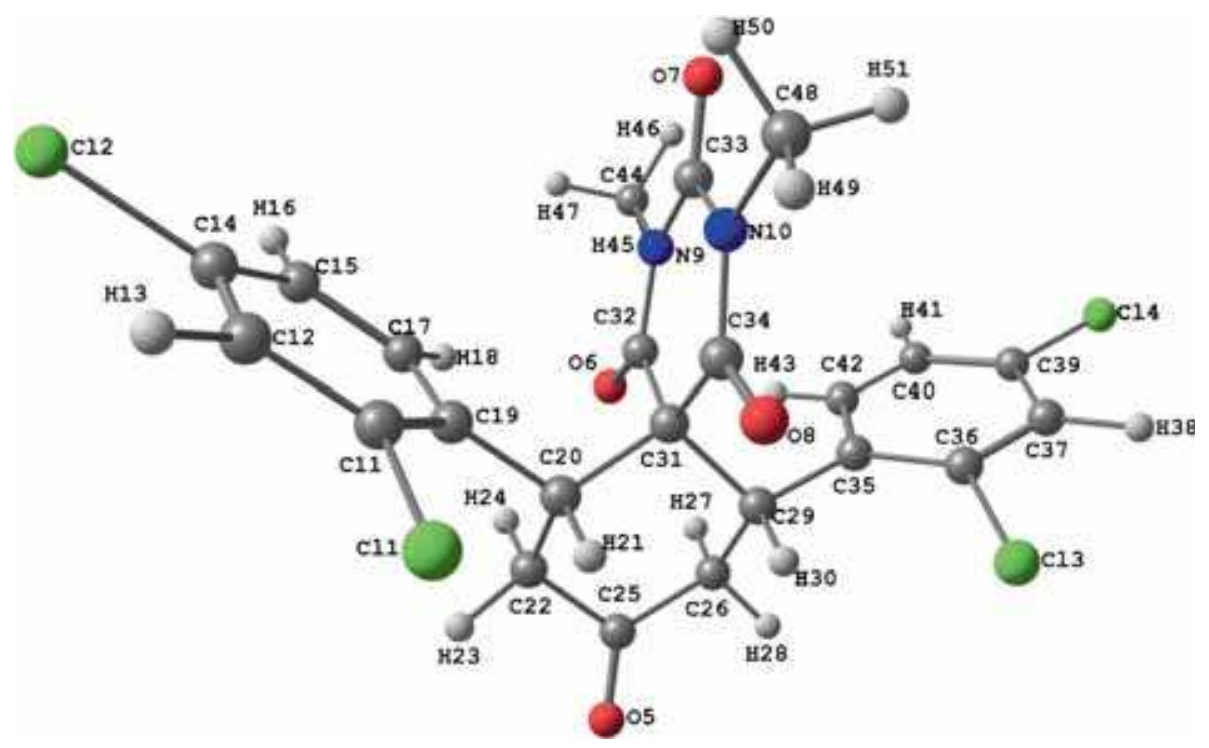

Figure 4. The optimized molecular structure of the title compound. 
Table 2. The experimental and calculated geometric parameters of the title compound using DFT B3LYP/6-311G(d,p) method.

\begin{tabular}{|c|c|c|c|c|c|}
\hline Parameter $^{\mathrm{a}}$ & Calc. & $\operatorname{Exp}$ & Parameter $^{\mathbf{a}}$ & Calc. & $\operatorname{Exp}$ \\
\hline $\mathrm{R}(1-11)$ & 1.758 & 1.735 & $\mathrm{~A}(8-34-31)$ & 120.1 & 121.3 \\
\hline $\mathrm{R}(2-14)$ & 1.754 & 1.735 & $\mathrm{~A}(32-9-33)$ & 125.5 & 125.3 \\
\hline $\mathrm{R}(3-36)$ & 1.758 & 1.742 & A(32-9-44) & 119.3 & 118.0 \\
\hline R(4-39) & 1.754 & 1.737 & $\mathrm{~A}(9-32-31)$ & 118.4 & 117.8 \\
\hline $\mathrm{R}(5-25)$ & 1.209 & 1.210 & $\mathrm{~A}(33-9-44)$ & 115.2 & 116.5 \\
\hline $\mathrm{R}(6-32)$ & 1.221 & 1.212 & $\mathrm{~A}(9-33-10)$ & 117.5 & 117.2 \\
\hline $\mathrm{R}(7-33)$ & 1.209 & 1.208 & $\mathrm{~A}(9-44-45)$ & 107.6 & 109.4 \\
\hline $\mathrm{R}(8-34)$ & 1.211 & 1.206 & $\mathrm{~A}(9-44-46)$ & 109.7 & 109.5 \\
\hline $\mathrm{R}(9-32)$ & 1.383 & 1.377 & $\mathrm{~A}(9-44-47)$ & 109.7 & 109.5 \\
\hline $\mathrm{R}(9-33)$ & 1.403 & 1.388 & $\mathrm{~A}(33-10-34)$ & 125.1 & 124.6 \\
\hline $\mathrm{R}(9-44)$ & 1.473 & 1.476 & $\mathrm{~A}(33-10-48)$ & 115.8 & 117.1 \\
\hline $\mathrm{R}(10-33)$ & 1.391 & 1.384 & $\mathrm{~A}(34-10-48)$ & 119.1 & 118.2 \\
\hline $\mathrm{R}(10-34)$ & 1.388 & 1.379 & $\mathrm{~A}(10-34-31)$ & 118.5 & 117.5 \\
\hline $\mathrm{R}(10-48)$ & 1.473 & 1.471 & $\mathrm{~A}(10-48-49)$ & 107.4 & 109.5 \\
\hline $\mathrm{R}(11-12)$ & 1.394 & 1.381 & $\mathrm{~A}(10-48-50)$ & 109.7 & 109.5 \\
\hline $\mathrm{R}(11-19)$ & 1.404 & 1.399 & $\mathrm{~A}(10-48-51)$ & 109.7 & 109.5 \\
\hline$R(12-14)$ & 1.387 & 1.364 & $\mathrm{~A}(12-11-19)$ & 122.2 & 121.8 \\
\hline $\mathrm{R}(14-15)$ & 1.390 & 1.369 & $\mathrm{~A}(11-12-14)$ & 119.2 & 119.4 \\
\hline $\mathrm{R}(15-17)$ & 1.389 & 1.386 & $\mathrm{~A}(11-19-17)$ & 116.3 & 116.1 \\
\hline $\mathrm{R}(17-19)$ & 1.404 & 1.392 & $\mathrm{~A}(11-19-20)$ & 122.7 & 122.6 \\
\hline $\mathrm{R}(19-20)$ & 1.525 & 1.526 & $\mathrm{~A}(13-12-14)$ & 120.7 & 120.3 \\
\hline $\mathrm{R}(20-22)$ & 1.544 & 1.536 & $\mathrm{~A}(12-14-15)$ & 120.8 & 121.6 \\
\hline $\mathrm{R}(20-31)$ & 1.587 & 1.596 & $\mathrm{~A}(14-15-17)$ & 118.8 & 118.2 \\
\hline$R(22-25)$ & 1.518 & 1.498 & $\mathrm{~A}(15-17-19)$ & 122.7 & 122.8 \\
\hline$R(25-26)$ & 1.518 & 1.505 & $\mathrm{~A}(17-19-20)$ & 121.0 & 121.1 \\
\hline$R(26-29)$ & 1.544 & 1.538 & $\mathrm{~A}(19-20-22)$ & 111.1 & 112.6 \\
\hline $\mathrm{R}(29-31)$ & 1.587 & 1.555 & $\mathrm{~A}(19-20-31)$ & 114.3 & 111.3 \\
\hline $\mathrm{R}(29-35)$ & 1.525 & 1.527 & $\mathrm{~A}(22-20-31)$ & 113.5 & 112.2 \\
\hline $\mathrm{R}(31-32)$ & 1.524 & 1.515 & $\mathrm{~A}(20-22-25)$ & 112.9 & 114.8 \\
\hline $\mathrm{R}(31-34)$ & 1.537 & 1.519 & $\mathrm{~A}(20-31-29)$ & 107.5 & 106.7 \\
\hline$R(35-36)$ & 1.404 & 1.399 & $\mathrm{~A}(20-31-32)$ & 111.0 & 107.8 \\
\hline$R(35-42)$ & 1.404 & 1.397 & $\mathrm{~A}(20-31-34)$ & 105.9 & 105.5 \\
\hline$R(36-37)$ & 1.394 & 1.383 & $\mathrm{~A}(22-25-26)$ & 115.5 & 117.7 \\
\hline R(37-39) & 1.387 & 1.375 & $\mathrm{~A}(25-26-29)$ & 112.9 & 113.5 \\
\hline $\mathrm{R}(39-40)$ & 1.390 & 1.371 & $\mathrm{~A}(27-26-29)$ & 110.5 & 108.9 \\
\hline $\mathrm{R}(40-42)$ & 1.389 & 1.390 & $\mathrm{~A}(26-29-31)$ & 113.5 & 113.1 \\
\hline $\mathrm{A}(1-11-12)$ & 116.1 & 116.9 & $\mathrm{~A}(26-29-35)$ & 111.1 & 110.9 \\
\hline $\mathrm{A}(1-11-19)$ & 121.7 & 121.3 & $\mathrm{~A}(31-29-35)$ & 114.3 & 115.6 \\
\hline $\mathrm{A}(2-14-12)$ & 119.3 & 119.5 & $\mathrm{~A}(29-31-32)$ & 111.0 & 114.5 \\
\hline $\mathrm{A}(2-14-15)$ & 119.9 & 118.9 & $\mathrm{~A}(29-31-34)$ & 105.9 & 107.8 \\
\hline $\mathrm{A}(3-36-35)$ & 121.7 & 120.7 & $\mathrm{~A}(29-35-36)$ & 122.7 & 120.7 \\
\hline $\mathrm{A}(3-36-37)$ & 116.1 & 116.3 & $\mathrm{~A}(29-35-42)$ & 121.0 & 124.0 \\
\hline $\mathrm{A}(4-39-37)$ & 119.3 & 118.8 & $\mathrm{~A}(32-31-34)$ & 115.1 & 114.0 \\
\hline $\mathrm{A}(4-39-40)$ & 119.9 & 120.3 & $\mathrm{~A}(36-35-42)$ & 116.3 & 115.3 \\
\hline $\mathrm{A}(5-25-22)$ & 122.2 & 121.4 & $\mathrm{~A}(35-36-37)$ & 122.2 & 123.0 \\
\hline $\mathrm{A}(5-25-26)$ & 122.2 & 120.8 & $\mathrm{~A}(35-42-40)$ & 122.7 & 122.8 \\
\hline $\mathrm{A}(6-32-9)$ & 120.7 & 120.0 & $\mathrm{~A}(35-42-43)$ & 119.1 & 118.6 \\
\hline $\mathrm{A}(6-32-31)$ & 120.9 & 122.1 & $\mathrm{~A}(36-37-39)$ & 119.2 & 119.0 \\
\hline $\mathrm{A}(7-33-9)$ & 120.8 & 121.6 & $\mathrm{~A}(37-39-40)$ & 120.8 & 120.9 \\
\hline $\mathrm{A}(7-33-10)$ & 121.7 & 121.2 & $\mathrm{~A}(39-40-42)$ & 118.8 & 119.0 \\
\hline $\mathrm{A}(8-34-10)$ & 121.4 & 121.0 & & & \\
\hline
\end{tabular}

${ }^{a}$ Atom numbering as in figure 4

the $\mathrm{O} 6$ and $\mathrm{O} 8$. The ring $\mathrm{C}$-atoms $(\mathrm{C} 25, \mathrm{C} 32, \mathrm{C} 33$ and $\mathrm{C} 34$ ) bonded to $\mathrm{N}$ - or $\mathrm{O}$-atoms are electropositive. The most electropositive carbon is $\mathrm{C} 33$ as it lies between two $\mathrm{N}$-atoms and one $\mathrm{O}$-atom. The rest of the $\mathrm{C}$-atoms are electronegative. All the $\mathrm{H}$ atoms are electropositive. 
Table 3. The natural atomic charges calculated at the level of B3LYP/6-311G(d,p).

\begin{tabular}{|c|c|c|c|}
\hline Atom & NAC & Atom & NAC \\
\hline $\mathrm{Cl1}$ & 0.0178 & $\mathrm{H} 27$ & 0.2375 \\
\hline $\mathrm{Cl} 2$ & 0.0077 & H28 & 0.2306 \\
\hline $\mathrm{Cl} 3$ & 0.0178 & C29 & -0.2060 \\
\hline $\mathrm{Cl} 4$ & 0.0077 & H30 & 0.2466 \\
\hline O5 & -0.5357 & C31 & -0.1819 \\
\hline O6 & -0.6388 & C32 & 0.7206 \\
\hline $\mathrm{O} 7$ & -0.5920 & C33 & 0.8529 \\
\hline O8 & -0.5906 & C34 & 0.7279 \\
\hline N9 & -0.4910 & C35 & -0.0747 \\
\hline N10 & -0.4924 & C36 & 0.0081 \\
\hline C11 & 0.0081 & C37 & -0.2496 \\
\hline C12 & -0.2496 & H38 & 0.2369 \\
\hline H13 & 0.2369 & C39 & -0.0017 \\
\hline C14 & -0.0017 & $\mathrm{C} 40$ & -0.2226 \\
\hline C15 & -0.2226 & H41 & 0.2233 \\
\hline H16 & 0.2233 & $\mathrm{C} 42$ & -0.1802 \\
\hline C17 & -0.1802 & H43 & 0.2223 \\
\hline H18 & 0.2223 & C44 & -0.3566 \\
\hline C19 & -0.0747 & H45 & 0.2220 \\
\hline $\mathrm{C} 20$ & -0.2060 & H46 & 0.2067 \\
\hline $\mathrm{H} 21$ & 0.2466 & H47 & 0.2068 \\
\hline $\mathrm{C} 22$ & -0.4781 & $\mathrm{C} 48$ & -0.3528 \\
\hline $\mathrm{H} 23$ & 0.2306 & H49 & 0.2263 \\
\hline $\mathrm{H} 24$ & 0.2375 & H50 & 0.2047 \\
\hline $\mathrm{C} 25$ & 0.6229 & H51 & 0.2047 \\
\hline $\mathrm{C} 26$ & -0.4781 & & \\
\hline
\end{tabular}

\subsection{Molecular electrostatic potential}

Electrostatic potential map (MEP) has been used to predict the reactive sites for electrophilic and nucleophilic attack, and in studies of biological recognition and hydrogen bonding interactions. ${ }^{25,26}$ It gives an idea on the charge distribution and charge related properties of molecules. The MEP of the studied compound calculated using B3LYP method with 6-311G(d,p) basis set is shown in figure 5. The electrostatic interactions between receptor active sites and a molecule play an important role in determining its bio-reactivity. It can be seen from this figure that, negative regions (red) are mainly localized over the O-atoms of the carbonyl groups while the maximum positive regions (blue) are localized over the ring $\mathrm{H}$-atom of the phenyl rings. The carbonyl $\mathrm{O}$-atoms and the phenyl group $\mathrm{H}$-atoms are the most reactive sites for electrophilic and nucleophilic attacks, respectively.

\subsection{Frontier molecular orbitals}

The shape of electron densities and energies of the frontier molecular orbitals (FMOs) are very useful for physicists and chemists. ${ }^{27}$ The energies of the highest occupied molecular orbital (HOMO) and the lowest unoccupied molecular orbital (LUMO) as well as their energy gap reflect the chemical reactivity of the molecule. The $\mathrm{E}_{\text {Hомо }}$ and $\mathrm{E}_{\mathrm{Lumo}}$ give idea about the ability of molecular system to lose and gain electrons, respectively. They reflect the chemical reactivity of molecules towards electron transfer process. The HOMO-LUMO energy gap $(\Delta \mathrm{E})$ represents the minimum energy needed for intramolecular electron transfer process. Moreover, the HOMO-LUMO energy gap has been used to prove the bioactivity from intramolecular charge transfer (ICT) ${ }^{28,29}$ The $\mathrm{E}_{\mathrm{HOMO}}$ and $\mathrm{E}_{\mathrm{LUMO}}$ of the studied molecule are calculated using the B3LYP/6$311 \mathrm{G}(\mathrm{d}, \mathrm{p})$ method. The HOMO and LUMO pictures are shown in figure 6. The $\mathrm{E}_{\mathrm{HOMO}}$ and $\mathrm{E}_{\mathrm{LUMO}}$ are calculated to be $-6.8951 \mathrm{eV}$ and $-1.9135 \mathrm{eV}$, respectively. The lowest energy electronic transition $(\Delta \mathrm{E})$ of the studied compound is $4.9816 \mathrm{eV}(248.88 \mathrm{~nm})$. This intramolecular charge transfer belongs mainly to $\pi-\pi^{*}$ excitation.

More accurate electronic transitions were calculated using the time-dependant density functional theory (TD-DFT). The spin allowed singlet-singlet electronic transitions calculated using the TD-DFT method were collected in table 4 . The calculated and experimental electronic spectra are shown in figure 7 . On the basis of calculations, the studied compound showed the most intense electronic transition band at $232 \mathrm{~nm}$. This band is predicted theoretically as shoulder at 231.3

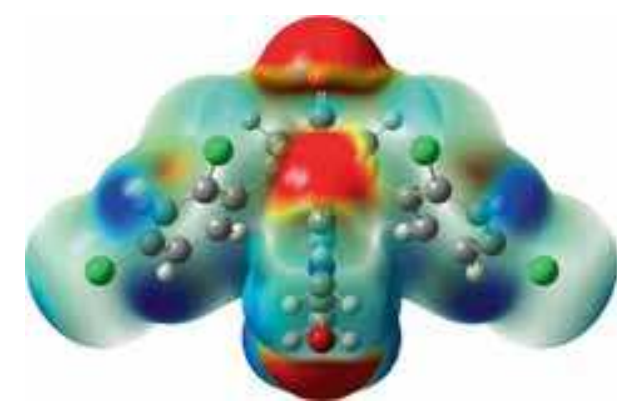

Figure 5. The ground state isodensity surface plots for the frontier molecular orbitals. 

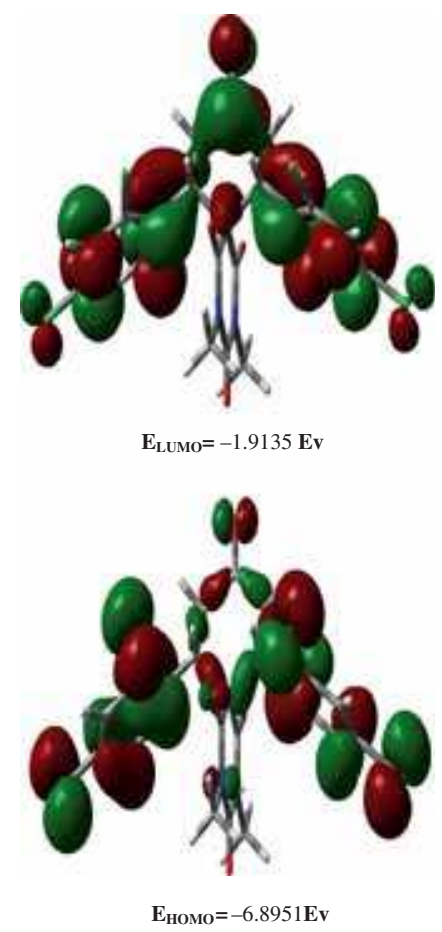

Figure 6. The ground state isodensity surface plots for the frontier molecular orbitals.

$\mathrm{nm}(\mathrm{f}=0.0832)$ and it belongs to $\mathrm{H}-3 / \mathrm{H}-1 \rightarrow \mathrm{L}+1$ and $\mathrm{H}-2 \rightarrow \mathrm{L}+2$ excitations.

\subsection{Chemical reactivity}

Based on the energies of the frontier molecular orbitals, various chemical reactivity descriptors such as electronegativity $(\chi)$, chemical potential $(\mu)$, chemical hardness $(\eta)$, global softness (S) and global electrophilicity index $(\omega)^{30-34}$ were proposed for understanding the different pharmacological aspects of drug molecules. These descriptors are calculated using Eqs (1)-(5) given below:

$$
\begin{gathered}
\chi=\frac{(I+A)}{2} \\
\mu=-\chi=-\frac{(I+A)}{2} \\
\eta=\frac{(I-A)}{2} \\
S=\frac{1}{2 \eta} \\
\omega=\frac{\mu^{2}}{2 \eta}
\end{gathered}
$$

The chemical hardness is a measure of the resistance to charge transference. ${ }^{35}$ It signifies the resistance towards the deformation of electron cloud of chemical systems under small perturbation encountered during chemical process. Soft systems are large and highly polarizable, while hard systems are relatively small and much less polarizable. On other hand, the electronegativity is a measure of the tendency to attract electrons in a chemical bond, as is defined as the negative of the chemical potential in DFT. ${ }^{36}$ The electrophilicity index $(\omega)$ measures the stabilization in energy when the system acquires an additional electronic charge from the environment. It contains information about both electron transfer (chemical potential) and stability (hardness) and is a better descriptor of global chemical reactivity (Eq. 5). For the studied compound, the ionization potential $\mathrm{I}=6.8951 \mathrm{eV}$, electron affinity $\mathrm{A}=1.9135 \mathrm{eV}$, global hardness $\eta=2.4908 \mathrm{eV}$, chemical potential $\mu=$ $-4.4043 \mathrm{eV}$, and global electrophilicity $\omega=3.8939 \mathrm{eV}$. It is seen that the chemical potential of the title compound is negative and it means that the compound is stable. It cannot decompose spontaneously into the elements they are made up of. Moreover, the low value of chemical potential and high value of electrophilicity index for the studied compound favor its electrophilic behavior. ${ }^{36}$

\section{$3.8 \quad$ NMR spectra}

The isotropic magnetic shielding (IMS) values calculated using the GIAO approach at the 6-311G(d,p) level are used to predict the ${ }^{13} \mathrm{C}$ and ${ }^{1} \mathrm{H}$ chemical shifts ( $\left.\delta_{\text {calc }}\right)$ for the title compound and the results are correlated to the experimental NMR data $\left(\delta_{\exp }\right)$ in $\mathrm{CDCl}_{3}$ solvent. The experimental and theoretical values for ${ }^{1} \mathrm{H}$ and ${ }^{13} \mathrm{C}$-NMR chemical shifts of the title compound are given in table S2 (Supplementary Information). According to these results, the calculated chemical shifts are in compliance with the experimental findings. As shown in figure 8, good correlations between the experimental and the calculated chemical shifts for carbon $\left(\mathrm{R}^{2}=0.991\right)$ and proton $\left(\mathrm{R}^{2}=0.934\right)$ were obtained. We noted some deviations for the calculated chemical shifts $\left(\delta_{\text {calc }}\right)$ of the H45 and H49 which are due to the presence of some weak C-H. . .O interactions (2.237-2.244 $\AA$ ) between these protons and the adjacent $\mathrm{O}$-atoms of the carbonyl groups. These interactions seem to overestimate the chemical shifts of these protons. Due to the known facts that these intramolecular interactions have no importance in solution, we decided to omit these two points from the correlation. As a result, better correlation coefficient was obtained $\left(\mathrm{R}^{2}=\right.$ $0.934)$. 
Table 4. The calculated electronic transition bands using TD-DFT method.

\begin{tabular}{|c|c|c|}
\hline$\lambda_{\max }(\mathbf{n m})$ & f & Major contributions \\
\hline 297.6 & 0.0104 & $\mathrm{H} \rightarrow \mathrm{L}+1(45 \%), \mathrm{H} \rightarrow \mathrm{L}+5(38 \%)$ \\
\hline 285.0 & 0.0006 & $\mathrm{H} \rightarrow \mathrm{L}(99 \%)$ \\
\hline 269.3 & 0.0001 & $\mathrm{H}-5 \rightarrow \mathrm{L}(79 \%)$ \\
\hline 259.0 & 0.0101 & $\mathrm{H}-2 \rightarrow \mathrm{L}(70 \%), \mathrm{H} \rightarrow \mathrm{L}+3(10 \%)$ \\
\hline 258.6 & 0.0019 & $\mathrm{H}-1 \rightarrow \mathrm{L}(83 \%)$ \\
\hline 253.9 & 0.0028 & $\mathrm{H}-1 \rightarrow \mathrm{L}(11 \%), \mathrm{H} \rightarrow \mathrm{L}+2(63 \%)$ \\
\hline 251.6 & 0.0027 & $\mathrm{H}-2 \rightarrow \mathrm{L}(26 \%), \mathrm{H}-2 \rightarrow \mathrm{L}+2(11 \%), \mathrm{H}-1 \rightarrow \mathrm{L}+1(12 \%), \mathrm{H} \rightarrow \mathrm{L}+3(32 \%)$ \\
\hline 247.5 & 0.1297 & $\mathrm{H} \rightarrow \mathrm{L}+1(44 \%), \mathrm{H} \rightarrow \mathrm{L}+3(15 \%), \mathrm{H} \rightarrow \mathrm{L}+5(31 \%)$ \\
\hline 243.7 & 0.0021 & $\mathrm{H}-2 \rightarrow \mathrm{L}+1(18 \%), \mathrm{H}-1 \rightarrow \mathrm{L}+2(15 \%), \mathrm{H} \rightarrow \mathrm{L}+2(29 \%), \mathrm{H} \rightarrow \mathrm{L}+4(18 \%)$ \\
\hline 241.1 & 0.0018 & $\mathrm{H}-3 \rightarrow \mathrm{L}(94 \%)$ \\
\hline 241.0 & 0.0056 & $\mathrm{H}-7 \rightarrow \mathrm{L}(34 \%), \mathrm{H}-5 \rightarrow \mathrm{L}+2(14 \%), \mathrm{H}-5 \rightarrow \mathrm{L}+6(12 \%), \mathrm{H}-4 \rightarrow \mathrm{L}(23 \%)$ \\
\hline 239.0 & 0.0102 & $\mathrm{H}-4 \rightarrow \mathrm{L}(26 \%), \mathrm{H}-1 \rightarrow \mathrm{L}+1(13 \%), \mathrm{H} \rightarrow \mathrm{L}+3(21 \%)$ \\
\hline 238.2 & 0.0350 & $\mathrm{H}-4 \rightarrow \mathrm{L}(37 \%), \mathrm{H} \rightarrow \mathrm{L}+3(17 \%)$ \\
\hline 235.9 & 0.0211 & $\mathrm{H} \rightarrow \mathrm{L}+4(71 \%)$ \\
\hline 231.3 & 0.0832 & $\mathrm{H}-3 \rightarrow \mathrm{L}+1(11 \%), \mathrm{H}-2 \rightarrow \mathrm{L}+2(23 \%), \mathrm{H}-1 \rightarrow \mathrm{L}+1(49 \%)$ \\
\hline 229.6 & 0.0148 & $\mathrm{H}-2 \rightarrow \mathrm{L}+1(50 \%), \mathrm{H}-1 \rightarrow \mathrm{L}+2(35 \%)$ \\
\hline 226.2 & 0.0153 & $\mathrm{H}-6 \rightarrow \mathrm{L}(84 \%)$ \\
\hline 224.6 & 0.0044 & $\mathrm{H}-5 \rightarrow \mathrm{L}+1(80 \%), \mathrm{H}-4 \rightarrow \mathrm{L}+1(15 \%)$ \\
\hline 223.0 & 0.0679 & $\mathrm{H}-3 \rightarrow \mathrm{L}+1(13 \%), \mathrm{H}-2 \rightarrow \mathrm{L}+2(37 \%), \mathrm{H}-1 \rightarrow \mathrm{L}+3(39 \%)$ \\
\hline 222.5 & 0.0107 & $\mathrm{H}-4 \rightarrow \mathrm{L}+1(10 \%), \mathrm{H}-2 \rightarrow \mathrm{L}+3(32 \%), \mathrm{H}-1 \rightarrow \mathrm{L}+2(24 \%)$ \\
\hline 219.1 & 0.0001 & $\mathrm{H}-7 \rightarrow \mathrm{L}(32 \%), \mathrm{H}-5 \rightarrow \mathrm{L}+2(36 \%)$ \\
\hline 218.4 & 0.0021 & $\mathrm{H} \rightarrow \mathrm{L}+6(84 \%)$ \\
\hline 217.4 & 0.0094 & $\mathrm{H}-9 \rightarrow \mathrm{L}(13 \%), \mathrm{H}-3 \rightarrow \mathrm{L}+1(25 \%), \mathrm{H}-2 \rightarrow \mathrm{L}+4(27 \%), \mathrm{H}-1 \rightarrow \mathrm{L}+3(17 \%)$ \\
\hline 217.1 & 0.0017 & $\mathrm{H}-11 \rightarrow \mathrm{L}(11 \%), \mathrm{H}-9 \rightarrow \mathrm{L}(42 \%)$ \\
\hline 217.1 & 0.0001 & $\mathrm{H}-2 \rightarrow \mathrm{L}+3(16 \%), \mathrm{H}-1 \rightarrow \mathrm{L}+4(60 \%)$ \\
\hline 214.3 & 0.0276 & $\mathrm{H}-4 \rightarrow \mathrm{L}+1(31 \%), \mathrm{H}-3 \rightarrow \mathrm{L}+2(45 \%)$ \\
\hline 214.3 & 0.0103 & $\mathrm{H}-4 \rightarrow \mathrm{L}+2(30 \%), \mathrm{H}-3 \rightarrow \mathrm{L}+1(17 \%), \mathrm{H}-2 \rightarrow \mathrm{L}+4(27 \%)$ \\
\hline 212.7 & 0.0004 & $\mathrm{H}-5 \rightarrow \mathrm{L}+3(85 \%), \mathrm{H}-4 \rightarrow \mathrm{L}+3(13 \%)$ \\
\hline 211.8 & 0.0045 & $\mathrm{H}-2 \rightarrow \mathrm{L}+8(20 \%), \mathrm{H}-1 \rightarrow \mathrm{L}+7(14 \%), \mathrm{H} \rightarrow \mathrm{L}+7(51 \%)$ \\
\hline 210.9 & 0.0033 & $\mathrm{H}-2 \rightarrow \mathrm{L}+7(27 \%), \mathrm{H}-1 \rightarrow \mathrm{L}+8(17 \%), \mathrm{H} \rightarrow \mathrm{L}+8(45 \%)$ \\
\hline 209.3 & 0.0969 & $\mathrm{H}-6 \rightarrow \mathrm{L}+1(52 \%)$ \\
\hline 208.7 & 0.0396 & $\mathrm{H}-6 \rightarrow \mathrm{L}+1(13 \%), \mathrm{H}-4 \rightarrow \mathrm{L}+2(14 \%), \mathrm{H}-3 \rightarrow \mathrm{L}+3(35 \%)$ \\
\hline 208.3 & 0.0007 & $\mathrm{H}-5 \rightarrow \mathrm{L}+4(76 \%), \mathrm{H}-4 \rightarrow \mathrm{L}+4(17 \%)$ \\
\hline 207.5 & 0.0851 & $\mathrm{H}-4 \rightarrow \mathrm{L}+3(19 \%), \mathrm{H}-3 \rightarrow \mathrm{L}+2(22 \%), \mathrm{H}-3 \rightarrow \mathrm{L}+4(17 \%)$ \\
\hline 206.8 & 0.0229 & $\mathrm{H}-4 \rightarrow \mathrm{L}+3(13 \%), \mathrm{H}-2 \rightarrow \mathrm{L}+5(25 \%), \mathrm{H}-1 \rightarrow \mathrm{L}+6(30 \%)$ \\
\hline 206.4 & 0.0060 & $\mathrm{H}-6 \rightarrow \mathrm{L}+1(21 \%), \mathrm{H}-5 \rightarrow \mathrm{L}+4(12 \%), \mathrm{H}-4 \rightarrow \mathrm{L}+4(10 \%), \mathrm{H}-1 \rightarrow \mathrm{L}+5(21 \%)$ \\
\hline 204.2 & 0.0365 & $\mathrm{H}-8 \rightarrow \mathrm{L}(42 \%), \mathrm{H}-6 \rightarrow \mathrm{L}+2(43 \%)$ \\
\hline 203.3 & 0.0584 & $\mathrm{H}-2 \rightarrow \mathrm{L}+6(43 \%), \mathrm{H}-1 \rightarrow \mathrm{L}+5(31 \%)$ \\
\hline 202.9 & 0.1379 & $\mathrm{H}-3 \rightarrow \mathrm{L}+3(23 \%), \mathrm{H}-2 \rightarrow \mathrm{L}+4(12 \%)$ \\
\hline 202.7 & 0.0701 & $\mathrm{H}-4 \rightarrow \mathrm{L}+3(12 \%), \mathrm{H}-3 \rightarrow \mathrm{L}+4(17 \%), \mathrm{H}-2 \rightarrow \mathrm{L}+5(13 \%), \mathrm{H}-1 \rightarrow \mathrm{L}+6(24 \%)$ \\
\hline
\end{tabular}

\subsection{Natural bond orbital (NBO) analysis}

The natural bond orbital (NBO) calculations were used to describe the most significant intramolecular charge transfer (ICT) interactions (table 5). The results showed the most important interactions between the filled NBOs of one bond and vacant orbitals of another one, which is a measure of the intramolecular delocalization of electrons. The stabilization energies $\mathrm{E}^{(2)}$ could be deduced from the NBO calculations using the second order perturbation analysis. ${ }^{37}$ The larger the stabilization energy $\mathrm{E}^{(2)}$, the more intensive is the interaction between electron donor and electron acceptor NBOs, i.e. greater is the extent of conjugation of the whole system. ${ }^{38}$ The ICT interactions formed by the orbital overlap between $\pi \rightarrow \pi^{*}, \mathrm{n} \rightarrow \sigma^{*}$ and $\mathrm{n} \rightarrow \pi^{*}$ caused stabilization of the system upto 21.37 , 26.55 and $59.87 \mathrm{kcal} / \mathrm{mol}$, respectively. The high $\mathrm{E}^{(2)}$ values of the $\mathrm{LP}(1) \mathrm{N} 9 \rightarrow \mathrm{BD} *(2) \mathrm{O} 6-\mathrm{C} 32 / \mathrm{BD} *(2) \mathrm{O} 7-$ $\mathrm{C} 33$ and $\mathrm{LP}(1) \mathrm{N} 10 \rightarrow \mathrm{BD} *(2) \mathrm{O} 7-\mathrm{C} 33 / \mathrm{BD} *(2) \mathrm{O} 8-\mathrm{C} 34$ ICT indicate the presence of strong electron delocalization from LPN9 and LPN10 to the neighboring $\mathrm{C}=\mathrm{O} \pi *$-NBOs. These results agree with the high negative charges observed at the $\mathrm{O}$-atoms of the carbonyl 

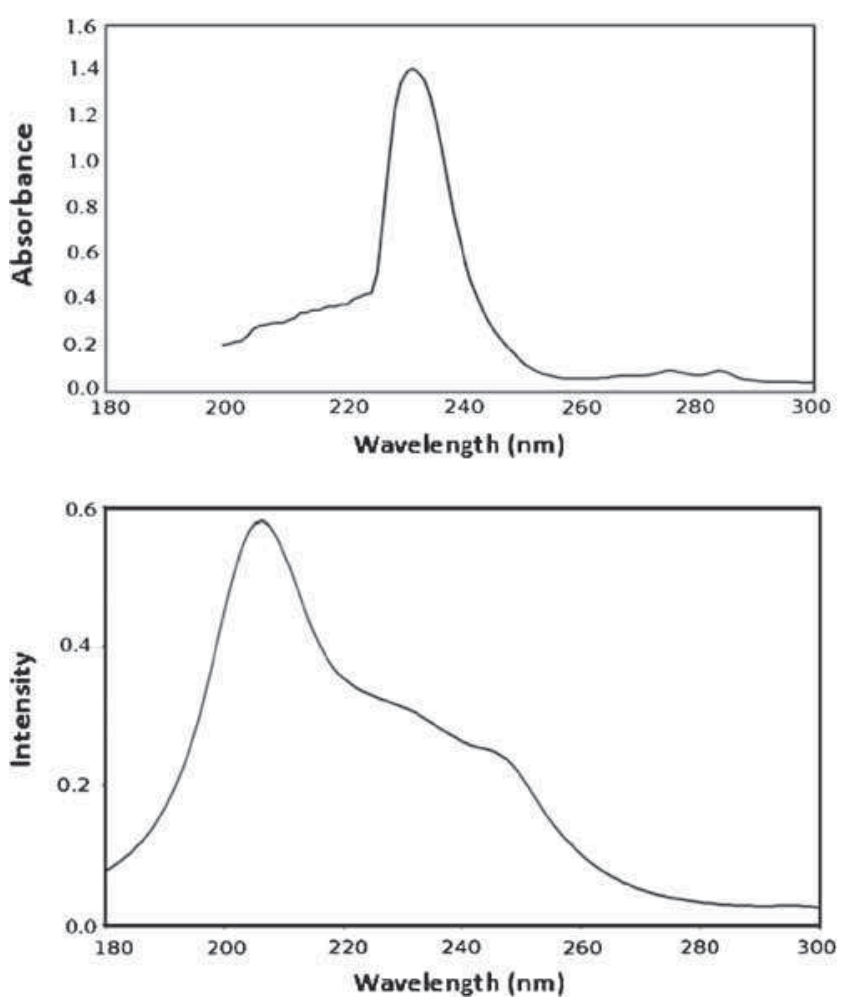

Figure 7. The experimental (upper) and calculated (lower) electronic spectra of the studied compound using TD-DFT method.

${ }^{1} \mathrm{H}$ NMR

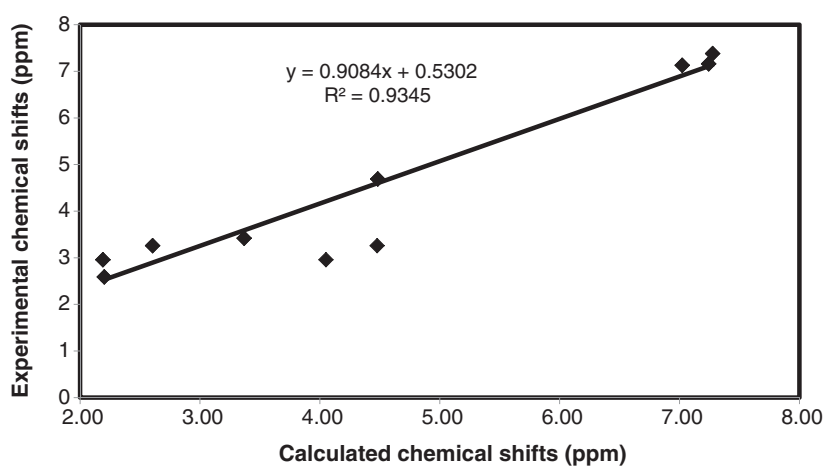

${ }^{13} \mathrm{C}$ NMR

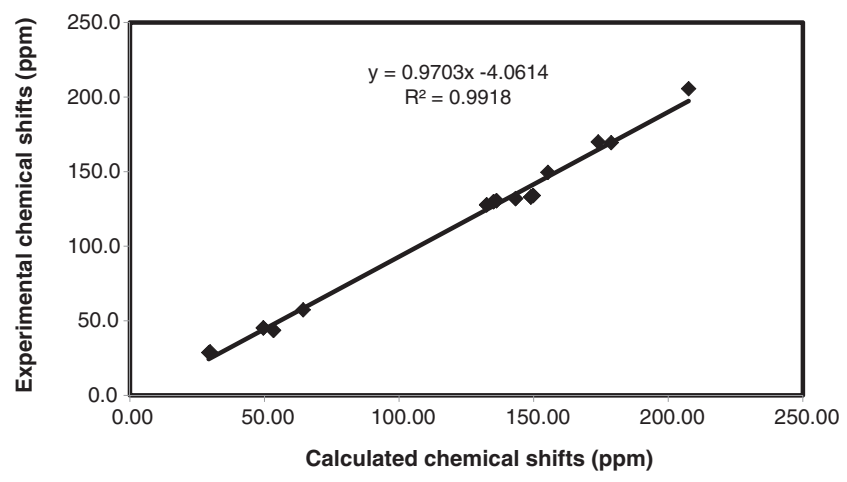

Figure 8. The correlation graphs between calculated and experimental ${ }^{1} \mathrm{H}-\mathrm{NMR}$ and ${ }^{13} \mathrm{C}-\mathrm{NMR}$ chemical shifts of the title compound. groups. The $\mathrm{LP}(3) \mathrm{Cl} \rightarrow\left(\mathrm{BD} *(2) \mathrm{C} 11-\mathrm{C} 19 / \mathrm{BD}^{*}(2) \mathrm{C} 12-\right.$ C14/BD*(2)C35-C36/BD*(2)C37-C39) ICT interactions indicate the delocalization of one of the $\mathrm{Cl}$-atom lone pairs within the phenyl $\pi$-ring system. These ICT stabilize the system upto $13.26 \mathrm{kcal} / \mathrm{mol}$. On other hand, the $\mathrm{LPO} \rightarrow \mathrm{BD} *(1) \mathrm{C}-\mathrm{H}$ ICT interactions shown in table 5 indicate that the $\mathrm{C}-\mathrm{H}-\mathrm{O}$ interactions are weak. Moreover, the stronger ICT from LP(N) to the BD*(1)C-H NBOs of the adjacent methyl groups has higher stabilization energies $(\sim 4.00 \mathrm{kcal} / \mathrm{mol})$. These results indicate the presence of some $\mathrm{N}-\mathrm{H}-\mathrm{C}$ interactions.

Table 5. The second order perturbation energies $E^{(2)}$ $(\mathrm{kcal} / \mathrm{mol})$ of the most important charge transfer interactions (donor-acceptor) of the title compound using B3LYP method.

\begin{tabular}{|c|c|c|}
\hline Donor NBO (i) & Acceptor NBO (j) & $\mathrm{E}^{(2)} \mathrm{kcal} / \mathrm{mol}$ \\
\hline $\mathrm{BD}(2) \mathrm{C} 11-\mathrm{C} 19$ & $\mathrm{BD}^{*}(2) \mathrm{C} 12-\mathrm{C} 14$ & 20.72 \\
\hline $\mathrm{BD}(2) \mathrm{C} 11-\mathrm{C} 19$ & $\mathrm{BD}^{*}(2) \mathrm{C} 15-\mathrm{C} 17$ & 19.15 \\
\hline $\mathrm{BD}(2) \mathrm{C} 12-\mathrm{C} 14$ & $\mathrm{BD} *(2) \mathrm{C} 11-\mathrm{C} 19$ & 18.96 \\
\hline $\mathrm{BD}(2) \mathrm{C} 12-\mathrm{C} 14$ & $\mathrm{BD}^{*}(2) \mathrm{C} 15-\mathrm{C} 17$ & 19.25 \\
\hline $\mathrm{BD}(2) \mathrm{C} 15-\mathrm{C} 17$ & $\mathrm{BD}^{*}(2) \mathrm{C} 11-\mathrm{C} 19$ & 20.40 \\
\hline $\mathrm{BD}(2) \mathrm{C} 15-\mathrm{C} 17$ & $\mathrm{BD} *(2) \mathrm{C} 12-\mathrm{C} 14$ & 21.37 \\
\hline $\mathrm{BD}(2) \mathrm{C} 35-\mathrm{C} 36$ & $\mathrm{BD}^{*}(2) \mathrm{C} 37-\mathrm{C} 39$ & 20.72 \\
\hline $\mathrm{BD}(2) \mathrm{C} 35-\mathrm{C} 36$ & $\mathrm{BD} *(2) \mathrm{C} 40-\mathrm{C} 42$ & 19.15 \\
\hline $\mathrm{BD}(2) \mathrm{C} 37-\mathrm{C} 39$ & $\mathrm{BD} *(2) \mathrm{C} 35-\mathrm{C} 36$ & 18.96 \\
\hline $\mathrm{BD}(2) \mathrm{C} 37-\mathrm{C} 39$ & $\mathrm{BD} *(2) \mathrm{C} 40-\mathrm{C} 42$ & 19.25 \\
\hline $\mathrm{BD}(2) \mathrm{C} 40-\mathrm{C} 42$ & $\mathrm{BD}^{*}(2) \mathrm{C} 35-\mathrm{C} 36$ & 20.40 \\
\hline $\mathrm{BD}(2) \mathrm{C} 40-\mathrm{C} 42$ & $\mathrm{BD} *(2) \mathrm{C} 37-\mathrm{C} 39$ & 21.37 \\
\hline LP(3)Cl1 & $\mathrm{BD}^{*}(2) \mathrm{C} 11-\mathrm{C} 19$ & 13.26 \\
\hline $\mathrm{LP}(3) \mathrm{Cl} 2$ & $\mathrm{BD} *(2) \mathrm{C} 12-\mathrm{C} 14$ & 12.96 \\
\hline $\mathrm{LP}(3) \mathrm{Cl} 3$ & $\mathrm{BD}^{*}(2) \mathrm{C} 35-\mathrm{C} 36$ & 13.26 \\
\hline LP(3)Cl4 & $\mathrm{BD}^{*}(2) \mathrm{C} 37-\mathrm{C} 39$ & 12.96 \\
\hline $\mathrm{LP}(2) \mathrm{O} 5$ & $\mathrm{BD} *(1) \mathrm{C} 22-\mathrm{C} 25$ & 20.51 \\
\hline $\mathrm{LP}(2) \mathrm{O} 5$ & $\mathrm{BD} *(1) \mathrm{C} 25-\mathrm{C} 26$ & 20.51 \\
\hline LP(2)O6 & BD*(1)N9-C32 & 25.22 \\
\hline LP(2)O6 & $\mathrm{BD} *(1) \mathrm{C} 31-\mathrm{C} 32$ & 17.90 \\
\hline $\mathrm{LP}(2) \mathrm{O} 7$ & BD*(1)N9-C33 & 26.51 \\
\hline LP(2)O7 & BD*(1)N10-C33 & 25.49 \\
\hline LP(2)O8 & BD*(1)N10-C34 & 26.55 \\
\hline $\mathrm{LP}(2) \mathrm{O} 8$ & $\mathrm{BD} *(1) \mathrm{C} 31-\mathrm{C} 34$ & 19.85 \\
\hline LP(1)N9 & BD*(2)O6-C32 & 59.87 \\
\hline LP(1)N9 & $\mathrm{BD} *(2) \mathrm{O} 7-\mathrm{C} 33$ & 50.34 \\
\hline LP(1)N10 & $\mathrm{BD} *(2) \mathrm{O} 7-\mathrm{C} 33$ & 54.55 \\
\hline LP(1)N10 & BD*(2)O8-C34 & 54.10 \\
\hline LP(2)O6 & BD*(1)C44-H45 & 0.72 \\
\hline LP(2)O7 & BD*(1)C44-H45 & 0.83 \\
\hline LP(2)O7 & BD*(1)C48-H49 & 0.75 \\
\hline LP(2)O8 & BD*(1)C48-H49 & 0.70 \\
\hline $\mathrm{LP}(2) \mathrm{Cl} 3$ & BD*(1)C29-H30 & 0.77 \\
\hline LP(2)Cl1 & $\mathrm{BD} *(1) \mathrm{C} 20-\mathrm{H} 21$ & 0.77 \\
\hline LP(1)N9 & BD*(1)C44-H46 & 4.01 \\
\hline LP(1)N 9 & BD*(1)C44-H47 & 4.00 \\
\hline LP(1)N10 & BD*(1)C48-H50 & 3.99 \\
\hline LP(1)N10 & BD*(1)C48-H51 & 3.98 \\
\hline
\end{tabular}




\section{Conclusions}

We conclude that the molecular structure of the title compound was deduced by X-ray single crystal and spectrophotometric techniques. The optimized geometric parameters (bond distances and bond angles) calculated using DFT/B3LYP method and 6-311G(d,p) basis set showed good agreement with our reported X-ray structure. Experimental UV-Vis spectrum of the title compound showed intense electronic transition band at $232 \mathrm{~nm}$. In accord with the experimental data, the TD-DFT calculated electronic transitions predicted a shoulder at about $231.3 \mathrm{~nm}$ which belongs to $\mathrm{H}-3 / \mathrm{H}-$ $1 \rightarrow \mathrm{L}+1$ and $\mathrm{H}-2 \rightarrow \mathrm{L}+2$ excitations. The NBO calculations were used to predict the different ICT interactions in the studied molecule. The stabilization energies $\mathrm{E}^{(2)}$ obtained from the analysis of the second order perturbation theory predicted strong electron delocaliztion from the $\mathrm{N}$-atom lone pair to the adjacent carbonyl groups. In addition, the $\mathrm{C}-\mathrm{H}-\mathrm{O}$ interactions are weaker than the N...H-C interactions.

\section{Supplementary Information}

All additional information pertaining to characterization of the target compound: The correlation graphs between calculated and observed geometrical parameters of the title compound are shown in figure S1. NMR (figures S2 and S3), IR (figure S4), H-bonding information (table S1) and NMR chemical shift data (table S2) are given in the Supplementary Information which is available at www.ias.ac.in/chemsci.

\section{Acknowledgements}

The authors would like to extend their sincere appreciation to the Deanship of Scientific Research at King Saud University for its funding this Research group NO (RG -044-1435-1436).

\section{References}

1. (a) Kotha S, Deb A C, Lahiri K and Manivannan E 2009 Synthesis 2009 165; (b) Bartoli A, Rodier F, Commeiras L, Parrain J L and Chouraqui G 2011 Nat. Prod. Rep. 28 763

2. Pradhan R, Patra M, Behera A K, Mishra B K and Behera R K 2006 Tetrahedron 62779

3. (a) Saragi T P I, Spehr T, Siebert A, Lieker T F and Salbeck J 2007 Chem. Rev. 107 1011; (b) Xie J H and Zhou Q L 2008 Acc. Chem. Res. 41 581; (c) Ding K, Han Z and Wang Z 2009 Chem.-Asian J. 432

4. Karatholuvhu M S, Sinclair A, Newton A F, Alcaraz M L, Stockman R A and Fuchs P L 2006 J. Am. Chem. Soc. 12812656
5. Taylor E C, Berrier J V, Cocuzza A J, Kobylecki R and McCormack J J 1977 J. Med. Chem. 201215

6. Naydenova E, Pencheva N, Popova J, Stoyanov N, Lazarova M and Aleksiev B 2002 Il Farmaco 57189

7. Takahashi S K, Witkop B, Brossi A, Maleque M A and Albuquerque E X 1982 Helv. Chim. Acta. 65252

8. Kim H S, Nagai Y, Ono K, Begum K, Wataya Y, Hamada Y, Tsuchiya K, Masuyama A, Nojima M and McCullough K J 2001 J. Med. Chem. 442357

9. Reddy D M, Qazi N A, Sawant S D, Bandey A H, Srinivas J, Shankar M, Singh S K, Verma M, Chashoo G, Saxena A, Mondhe D, Saxena A K, Sethi V K, Taneja S C, Qazi G N and Kumar H M S 2011 Eur. J. Med. Chem. 463210

10. (a) Srivastav N, Mittal A and Kumar A, 1992 J. Chem. Soc. 493; (b) Longeon A, Guyot M, Vacelet J 1990 Experentia 46548

11. Osman A N, Kandeel M M, Said M M and Ahmed E M 1996 Indian J. Chem. Sect. B: Org. Chem. Incl. Med. Chem. 351073

12. Behera R K, Behera A K, Pradhan R, Pati A and Patra M 2009 Phosphorus, Sulfur Silicon Relat. Elem. 184753

13. Kesharwani S, Sahu N K and Kohli D V 2009 Pharm. Chem. J. 43315

14. Goel B, Sharma S, Bajaj K, Bansal D, Singh T, Malik N, Lata S, Tyagi C, Panwar H, Agarwal A and Kumar A 2005 Indian J. Pharm. Sci. 67194

15. Behera R K, Behera A K, Pradhan R, Pati A and Patra M 2006 Synth. Commun. 363729

16. (a) Theford D, Chorton A P and Hardman J 2003 Dyes Pigm. 59 185; (b) Karci F 2008 Dyes Pigm. 77 451; (c) Wang S and Kim S H 2009 Dyes Pigm. 80314

17. (a) Michael A J 1887 Prakt Chem. 35 349; (b) Jung M E 1991 In Comprehensive Organic Synthesis Vol. 4 B M Trost, I Fleming and M F Semmelhack (Eds.) (Oxford: Pergamon) pp 1-68; (c) Perlmutter P 1992 In Conjugate Addition Reactions in Organic Synthesis (New York: Elsevier Science); (d) Barakat A, Islam M S, Al Majid A M A and Al-Othman Z A 2013 Tetrahedron 69 5185; (e) Islam M S, Al Majid A M A, Al-Othman Z A, Barakat A 2014 Tetrahedron: Asymmetry 25 245; (f) Al Majid A M A, Islam M S, Barakat A, Al-Agamy M H M and Naushad M 2014 The Scientific World Journal, doi: 10.1155/2014/649197; (g) Barakat A, Islam M S, Al-Majid A M, Ghabbour H A, Fun H-K, Javed K, Imad R, Yousuf S, Choudhary M I and Wadood A 2015 Bioorg. Med. Chem. 23 740; (h) Barakat A, Al Majid A M, Islam M S, Soliman S M, Siddiqui M R H, Ghabbour H A and Fun H-K $2015 \mathrm{~J}$. Chem. Sci. doi: 10.1007/s12039-015-0923-X

18. Sheldrick G M 2008 Acta Cryst. A 64112

19. Spek A L 2009 Acta Cryst. D 65148

20. (a) www.gaussian.com; (b) Frisch M J, Trucks G W, Schlegel H B, Scuseria G E, Robb M A and Cheeseman J R Gaussian-03, Revision C.01 2004 (Wallingford, CT, USA: Gaussian, Inc.)

21. Dennington R II, Keith T and Millam J, Gauss View, Version 4.1.2 2007 (Shawnee Mission, KS, USA: Semichem Inc.)

22. Zhurko G A and Zhurko D A 2005 ChemCraft: Tool for Treatment of Chemical Data, Late version build 08 (freeware). http://www.chemcraftprog.com (accessed on 5 May 2015) 
23. Glendening E D, Reed A E, Carpenter J E and Weinhold F 1998 NBO Version 3.1 TCI (Madison, WI, USA: University of Wisconsin)

24. Islam M S, Barakat A, Al Majid A M A, Ghabbour $\mathrm{H}$ A, Fun H-K and Siddiqui M R 2015 Arab. J. Chem. doi: 10.1016/j.arabjc.2015.03.007

25. Murray J S and Sen K 1996 In Molecular Electrostatic Potentials, Concepts and Applications (Amsterdam: Elsevier)

26. Scrocco E and Tomasi J 1978 Adv. Quantum. Chem. 11 115

27. Fukui K, Yonezawa T and Shingu H J 1952 J. Chem. Phys. 20722

28. Padmaja L, Ravikumar C, Sajan D, Joe I H, Jayakumar V S, Pettit G R and Neilsen F O 2009 J. Raman Spectrosc. 40419

29. Ravikumar C, Joe I H and Jayakumar V S 2008 Chem. Phys. Lett. 460552
30. Pearson R G 1989 J. Org. Chem. 541430

31. Parr R G and Pearson R G 1983 J. Am. Chem. Soc. 105 7512

32. Geerlings P, De-Proft F and Langenaeker W 2003 Chem. Rev. 1031793

33. Parr R G, Szentpaly L and Liu S 1999 J. Am. Chem. Soc. 1211922

34. Chattaraj K and Giri S 2007 J. Phys. Chem. A 11111116

35. Parr R G, and Yang W 1989 In Density-Functional Theory of Atoms and Molecules (New York: Oxford University Press)

36. Singh R N, Kumar A, Tiwari R K, Rawat P and Gupta V P 2013 J. Mol. Struct. 1035427

37. Joe I H, Kostova I, Ravikumar C, Amalanathan M and Pinzaru S C 2009 J. Raman Spectrosc. 40 1033

38. Sebastian S and Sundaraganesan N 2010 Spectro. Chim. Acta Part A 75941 